УДК 664.1.038

\title{
THE RESEARCH OF EJECTOR WITH A COMPACT AND ATOMIZED LIQUID JET FOR SULPHITATION IN THE SUGAR INDUSTRY
}

\author{
Ya. Khitriy, V. Ponomarenko \\ National University of Food Technologies
}

\begin{tabular}{|c|c|}
\hline Key words: & ABSTRACT \\
\hline $\begin{array}{l}\text { Sulphitation } \\
\text { Nozzle } \\
\text { Ejector } \\
\text { Mixing chamber } \\
\text { Laboratory setup } \\
\text { Volume ratio ejection }\end{array}$ & $\begin{array}{l}\text { This article is devoted to the study of the hydrodynamics of } \\
\text { two-phase flow in an ejection device with an extended } \\
\text { mixing chamber and a compact dispersed liquid jet. The } \\
\text { scientific literature describing the operation of various types } \\
\text { of sulfitators has been analyzed, and jet type machines have } \\
\text { been pointed out to be the most common. The operation of }\end{array}$ \\
\hline $\begin{array}{l}\text { Article history: } \\
\text { Received 14.11.2017 } \\
\text { Received in revised form } \\
30.11 .2017 \\
\text { Accepted 11.12.2017 }\end{array}$ & $\begin{array}{l}\text { the jet type sulfitators has been studied, their defects have } \\
\text { been revealed and main directions of their modernization } \\
\text { have been indicated. In order to establish jet patterns of the } \\
\text { fluid in the ejection device, a laboratory facility, which } \\
\text { design has been described in this work, has been designed }\end{array}$ \\
\hline $\begin{array}{l}\text { Corresponding author: } \\
\text { Ya. Khitriy } \\
\text { E-mail: } \\
\text { npnuht@ukr.net }\end{array}$ & $\begin{array}{l}\text { and manufactured. By experiments we managed to establish } \\
\text { the dependence of the ejection coefficient on the main geo- } \\
\text { metric characteristic when using it as a motive nozzle of jet } \\
\text { and centrifugal-jet nozzles. The analysis of the results allo- } \\
\text { wed determining the values of optimal geometric characte- } \\
\text { ristics of the ejector for all types of jet machines. }\end{array}$ \\
\hline
\end{tabular}

DOI: $10.24263 / 2225-2924-2017-23-6-11$

\section{ДОСЛІДЖЕННЯ ЕЖЕКТОРІВ 3 КОМПАКТНИМ І ДИСПЕРГОВАНИМ СТРУМЕНЕМ РІДИНИ ДЛЯ СУЛЬФІТАТОРІВ У ЦУКРОВІЙ ПРОМИСЛОВОСТІ}

\author{
Я.С. Хитрий, В.В. Пономаренко \\ Національний університет харчових технологій
}

У статті досліджено гідродинаміку течії двофазного потоку в ежекиійному апараті з подовженою камерою змішування та компактним і диспергованим струменем рідини. Проаналізовано наукову літературу, в якій описано роботу сульфітаторів різних типів $i$ зазначено, що найпоширенішими є апарати струминного типу. Розглянуто роботу сульфітаторів струминного типу, виявлено недоліки та вказано основні напрями їх модернізачії. Для встановлення закономірностей течії рідини в ежекиійному апараті спроектовано та виготовлено лабораторну установку, конструкцію якої описано в статті. Дослідами встановлено залежність коефіиієнта ежекиії від основної геометричної характеристики при використанні як робочого сопла струминної 
та відиентрово-струминної форсунок. Аналіз отриманих результатів дав змогу визначити значення оптимальної геометричної характеристики ежектора для всіх типів розпилювачів.

Ключові слова: сульфітатор, форсунка, ежектор, камера змішування, лабораторний стенд, об 'ємний коефіиієнт ежекиії.

Постановка проблеми. Сульфітація води $\epsilon$ важливим процесом у технологічній ланці цукрового заводу, яка передбачає оброблення рідини сірчистим ангідридом 3 метою встановлення регламентованого значення $\mathrm{pH}$, пригнічення життєдіяльності мікроорганізмів і стерилізації. Від якості іiі проведення залежить ефективність роботи дифузійних апаратів і ступінь знецукрення стружки.

На цукрових заводах для сульфітації використовують апарати різних типів: зрошувальні, барботерні, струминні [1], а також їх модифікації, наприклад, сульфітатор з вібруючими пластинами, основою конструкції якого $є$ зрошувальний сульфітатор [2].

Сульфітатори зрошувального та барботажного типу мають суттєві недоліки: неповне використання (близько 70\%) ангідриду сірки внаслідок його недостатнього контакту з рідиною, значне забруднення атмосфери, великі габаритні розміри та висока питома металомісткість [2].

Сульфітатори $з$ вібруючими пластинами показали свою ненадійність під час роботи внаслідок зниження пружних властивостей гумових пластин [1].

Найпоширенішими є сульфітатори струминного типу. Вони прості у виготовленні й обслуговуванні, компактні, мають низьку питому металомісткість. Проте за час їх експлуатації виявлено низку недоліків, а саме:

- низький термін служби окремих деталей унаслідок контакту з агресивним середовищем;

- низький коефіцієнт використання сульфітаційного газу, що спричинює корозію витяжної труби;

- низька інтенсивність процесу масообміну між газовою та рідкою фазами, що призводить до невідповідності регламентним значенням $\mathrm{pH}$;

- загазованість робочого місця.

Виявлені недоліки усувають модернізацією апаратів сульфітації. Одним із напрямів модернізації, спрямованим на збільшення терміну служби, є заміна матеріалу деталей сульфітатора 3 чавуну на нержавійну сталь [3]. Це дало змогу підвищити термін служби та зменшити питому масу сульфітатора. Проте через значну вартість нержавійної сталі не кожен споживач готовий на таке рішення. Інші пропозиції стосуються виконання елементів корпусу апарата з полімерного матеріалу.

Напрямом інтенсифікації процесу масообміну та підвищення коефіцієнта використання сульфітаційного газу є також удосконалення конструкції струминного апарата сульфітатора. Пропонується в камері змішування сульфітатора встановлювати завихрювачі, які інтенсифікують процеси масообміну за рахунок турбулізації потоку рідини [4].

У сульфітаторах типової конструкції як розпилювач використано диск 3 отворами, який формально є струминною форсункою з малим кутом розпиле- 
ння, а формування на краплі відбувається на великій відстані від сопла форсунки. у результаті цього отримують компактний струмінь з невеликою площею контакту. Проте для ефективного проведення масообмінних процесів важливе значення має площа контакту фаз. Значно збільшити ії можна заміною типу розпилювача: диска 3 отворами (струминна форсунка) на відцентровоструминну форсунку [5]. Це забезпечує рівномірне заповнення площі поперечного перерізу камери змішування конічним факелом розпиленої рідини 3 кутом розкриття $40 \ldots 60^{\circ}$. Для регулювання витрати рідини через апарат доцільно встановлювати регульовану відцентрово-струминну форсунку 3 нахиленим розміщенням підвідних каналів [6]. Ї̈̈ переваги:

- можливість регулювання в широких межах витрати рідини;

- надійність роботи завдяки достатньо великим прохідним перерізам;

- дрібнодисперсне розпилення рідини, що забезпечує високу поверхню та інтенсивну масопередачу.

Ефективність роботи сульфітатора можна підвищити вдосконаленням конструкції самої камери змішування:

- встановлення в ній напрямного апарата [7] для турбулізації пристінних шарів [8], що інтенсифікує процес масопередачі;

- встановлення в камері змішування сітки для додаткового подрібнення та швидшого вирівнювання профілів концентрацій, тисків [9].

Перелічені роботи 3 удосконалення сульфітаційних апаратів виконували виходячи з накопиченого досвіду, іноді на інтуїтивному рівні без належного дослідження його гідродинаміки, що не дає змоги науково обгрунтовано підійти до визначення основних геометричних розмірів ежектора та його проектування.

Мета дослідження: для проектування ежектора високої ефективності встановити залежність коефіцієнта ежекції від основної геометричної характеристики при використанні як робочого сопла струминної та відцентровоструминної форсунок (ежектор з диспергованою струминою та подовженою камерою змішування).

Матеріали і обладнання. Для дослідження гідродинаміки ежекційного апарата створено лабораторну установку. Тиск контролювали за допомогою манометра пружинного типу ОБМ1-160. Витрату рідини вимірювали лічильником води ЕТМ КВ 1,5. Витрату газу вимірювали газовим лічильником PREMA G1,6. Розрідження в приймальній камері ежектора контролювали диференційним манометром. Фотозйомку течії рідини в камері змішування проведено за допомогою цифрової фотокамери Canon SX130.

Методика оброблення експериментальних даних. Оброблення експериментальних даних і побудову графіків виконано за допомогою табличного процесора Microsoft Office Excel.

Результати і обговорення. Для встановлення закономірностей течії двофазного потоку в ежекційному апараті спроектовано та виготовлено лабораторну установку (рис. 1), до складу якої входить ежекційний пристрій, що є подовженою камерою змішування 9, приймальна камера 8, форсунка 7 та патрубки подачі рідини і газу. Рідина до розпилювача 7 ежектора подається насосом 1 під тиском, що контролюється манометром 6. Витрату рідини регулювали за допомогою крана 4. 
Витрати рідини та газу контролювали за допомогою витратомірів 5, 12 об’ємного типу. Розрідження в ежекторі вимірювали дифманометром 11.

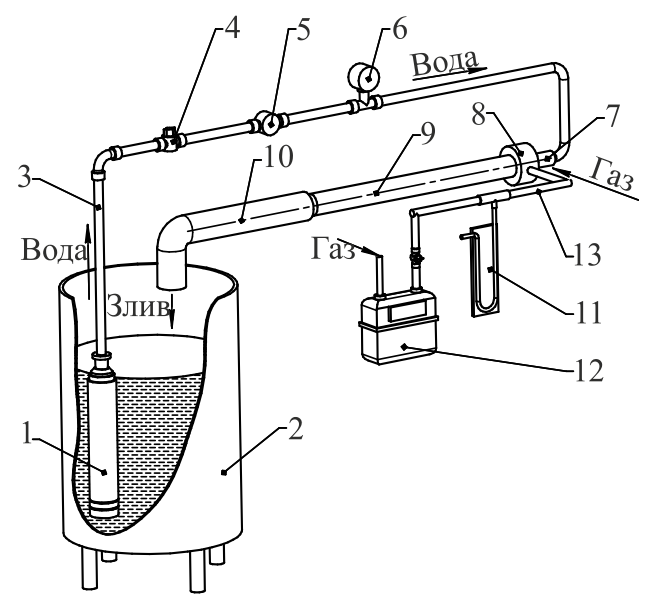

Рис. 1. Експериментальна установка:

1 - насос; 2 - місткість; 3 - трубопровід; 4 - регулювальна арматура; 5 - витратомір рідини; 6 - манометр; 7 - форсунка; 8 - приймальна камера; 9 - камера змішування; 10 - зливний трубопровід; 11 - дифманометр; 12 - витратомір газу; 13 - газопровід

Для візуального спостереження та фотозйомки течії емульсії в камері змішування використано скляну трубу, а воду, що циркулює в системі, забарвлено харчовим барвником.

Завдання першого етапу досліджень полягало в установленні закономірностей гідродинаміки течії рідини в ежекційному апараті, в якому як розпилювач використано струминну форсунку (рис. 2) з різними діаметрами сопел $d_{c}=3,4,6,8$ мм. Тиск рідини змінювався в межах 0,05-0,245 МПа. Низькі тиски рідини характерні для роботи насосів цукрового заводу, тому аналіз роботи ежекторів за таких тисків є практичним завданням. Як камери змішування використано прозорі трубки діаметром, $d_{\kappa .3 .}=8,15,19,27,45$ мм.

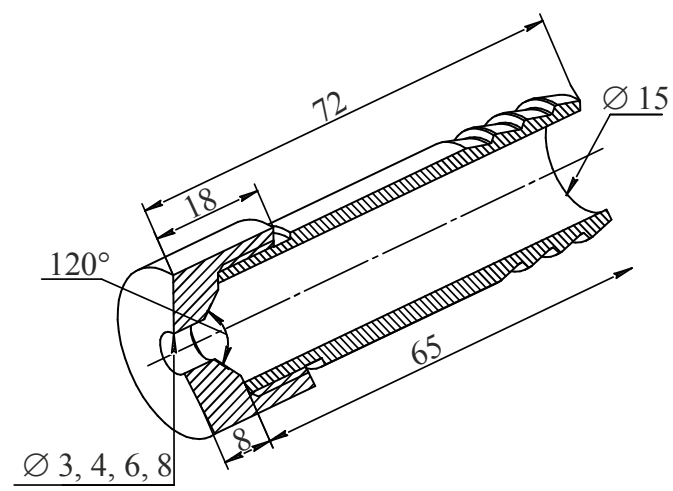

Рис. 2. Конструкція струминної форсунки, яку використано для дослідів

Під час дослідження роботи ежектора $3 d_{c}=4 \mathrm{mм} \mathrm{i} d_{\kappa .3 .}=45$ мм (геометрична характеристика $\left.d_{\kappa .3 .} / d_{c}=11,25\right)$ встановлено, що коефіцієнт ежекції 
рівний нулю. Струмінь рідини не торкається стінок камери змішування, що створює умови для циркуляції газу в зону зниженого тиску виходу рідини із сопла форсунки 3 боку відкритого торця камери змішування. Режим течії наочно ілюструє фото за тиску рідини на форсунці $P=1,47 \cdot 10^{5}$ Па (рис. 3 ). У типовому сульфітаторі ПСК геометрична характеристика ежектора становить 10,2, що відповідає описаному режиму роботи за відсутності ежекції.

Отже, дослідами встановлено причину відсутності ежекції під час роботи типового сульфітатора. У такому режимі опір вхідному газовому потоку в приймальну камеру перевищує опір входу газу з торця камери змішування, що призводить до відсутності ежекції та загазованості робочого місця.

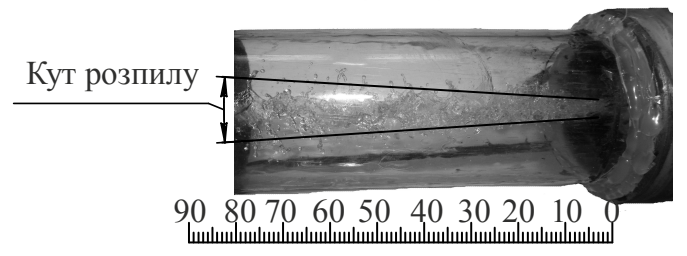

Рис. 3. Характерний режим течії рідини в ежекторі зі струминною форсункою

Подальші досліди ежектора зі струминною форсункою, яка має змінні діаметри сопел (рис. 4) і різні діаметри камери змішування, дали змогу встановити залежність об'ємного коефіцієнта ежекції від його головної геометричної характеристики, що змінювалась у межах від 2 до 11,25 (табл. 1).

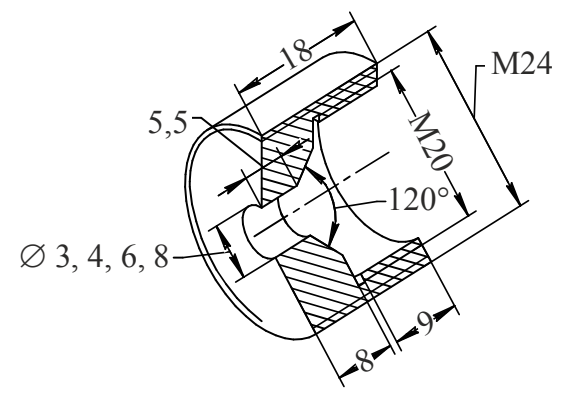

Рис. 4. Конструкція змінного сопла для форсунки

Табличя 1. Геометрична характеристика $d_{\text {к.з. }} / d_{\mathrm{c}}$ ежекційного пристрою

\begin{tabular}{|c|c|c|c|c|c|}
\hline \multirow{2}{*}{ Діаметр сопла, мм } & \multicolumn{5}{|c|}{ Діаметр камери змішування, мм } \\
\cline { 2 - 6 } & 8 & 15 & 19 & 27 & 45 \\
\hline 3 & 2,67 & 5,00 & 6,33 & 9,00 & - \\
\hline 4 & 2,00 & 3,75 & 4,75 & 6,75 & 11,25 \\
\hline 6 & - & 2,50 & 3,17 & 4,50 & 7,50 \\
\hline 8 & - & - & 2,38 & 3,38 & 5,63 \\
\hline
\end{tabular}

Об'ємний коефіцієнт ежекції $u$ (відношення витрати пасивного потоку до витрати активного) визначають за формулою:

$$
u=Q_{\text {газ }} / Q_{\text {рід }},
$$

де $Q_{\text {газ }}-$ витрата газу, м $3 / \mathrm{c} ; Q_{\text {рід }}-$ витрата рідини, м $^{3} / \mathrm{c}$. 
На основі експериментальних даних побудовано графіки залежності коефіцієнта ежекції від тиску рідини за різної геометричної характеристики ежектора. Для прикладу наведемо графік залежності коефіцієнта ежекції від геометричної характеристики $d_{\text {к.3 }} / d_{\mathrm{c}}$ (рис. 5), за тисків рідини $(0,735,1,47,1,96) \cdot 10^{5}$ Па.

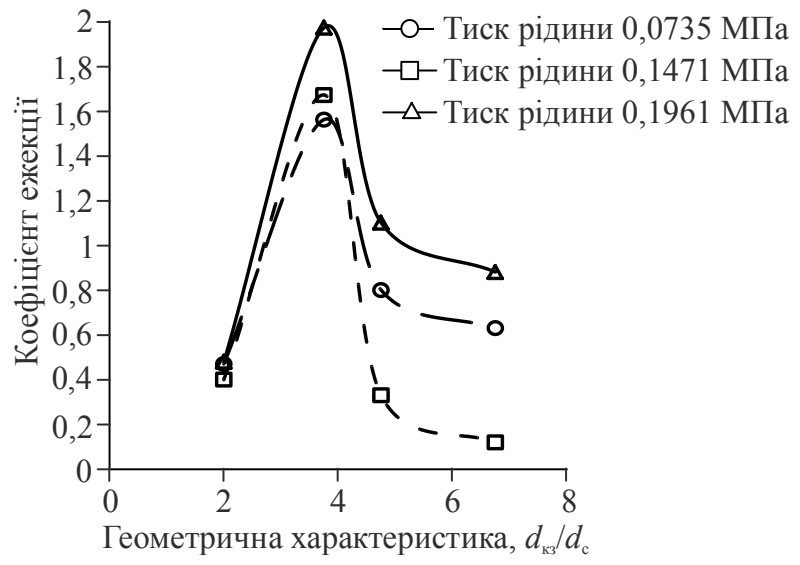

Рис. 5. Залежність об’'много коефіціснта ежекції від відношення $d_{\text {к.3. }} / d_{\mathrm{c}}$ для ежектора зі струминною форсункою

Згідно з графіком, зображеним на рис. 5, коефіцієнт ежекції за однакового тиску на форсунці, але 3 різною головною геометричною характеристикою ежектора набуває числових значень, що значно відрізняються, від максимальних значень за оптимальної геометричної характеристики ежектора, яка в усіх дослідах становить $4,5 \ldots 5,5$.

Отже, встановлено, що ежекційний апарат типового сульфітатора, головна геометрична характеристика якого становить 10,2 , працює за межами оптимуму, що не дає змоги отримати достатню кількість сульфітаційного газу для ефективного перебігу процесу.

Другим етапом дослідження роботи ежектора було встановлення залежності об'ємного коефіцієнта ежекції від основної геометричної характеристики ежектора за зміни типу розпилювача: струминної форсунки на відцентрово-струминну (рис. 6). Для цього використано корпус струминної форсунки, в якому розміщено вставку з чотирма нахиленими каналами та центральним отвором.

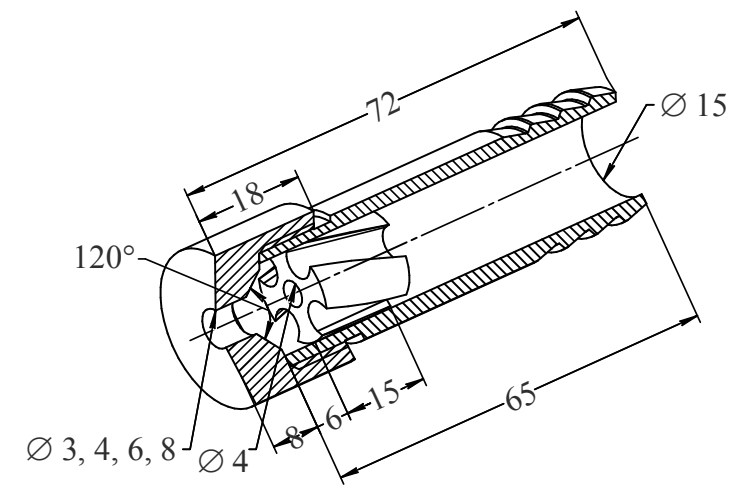

Рис. 6. Конструкція форсунки відцентрово-струминного типу з центральною вставкою 
Заміна типу розпилювача зі струминного на відцентрово-струминний привела до зміни факела розпилення (рис. 7), який характеризується повністю заповненим факелом з кутом розпилення близько $40^{\circ}$. Факел торкається стінок камери змішування ежектора на незначній відстані від сопла, що гарантує утворення зони пониженого тиску в приймальній камері.

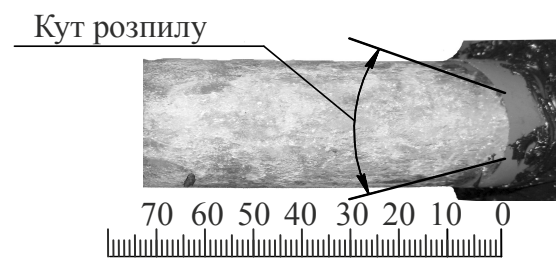

Рис. 7. Характерний режим течії рідини в ежекторі з відцентрово-струминною форсункою

На відміну від струминної форсунки, яка показала відсутність коефіцієнта ежекції в камері змішування діаметром $d_{\text {к.з. }}=45$ мм, заміна типу розпилювача на відцентрово-струминний дала можливість якісно змінити картину гідродинаміки течії в ежекторі, гарантовано отримати розрідження в приймальній камері змішування та досягти більш стабільної роботи і зменшення загазованості робочого місця за рахунок збільшення тяги. Наведемо залежність коефіцієнта ежекції від тиску рідини на відцентрово-струминній форсунці (рис. 8) 3 камерою змішування $d_{\mathrm{k} .3 .}=45$ мм та різними діаметрами сопел $d_{\mathrm{c}}=4,6,8$ мм.

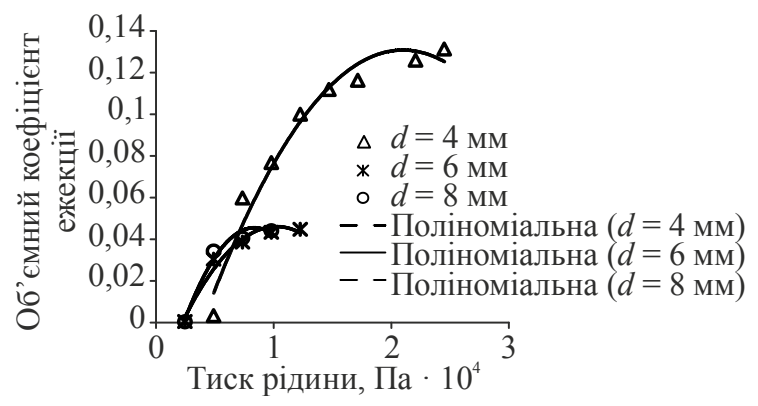

Рис. 8. Залежність коефіціснта ежекції від тиску на відцентрово-струминній форсунці

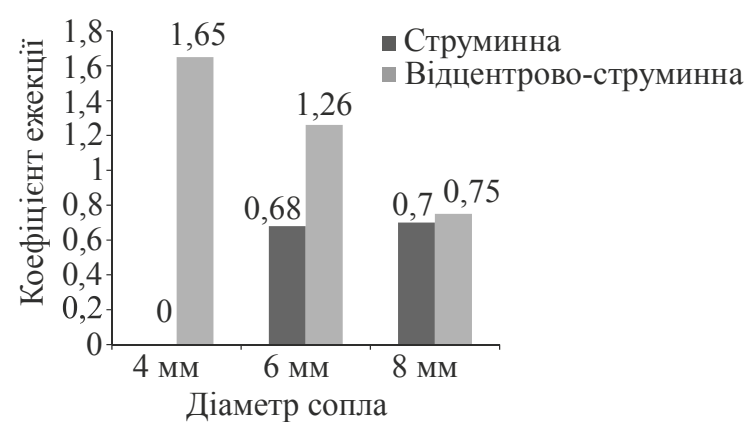

Рис. 9. Залежність коефіціснта ежекції від діаметра сопла для різних типів форсунок при камері змішування $\boldsymbol{d}_{\kappa .3}=15$ мм, тиск рідини $0,735 \cdot 10^{5}$ Па 
У ході дослідження встановлено, що при використанні форсунки відцентрово-струминного типу можна досягти більшого коефіцієнта ежекції за однакової витрати рідини порівняно зі струминною форсункою (рис. 9).

На рис. 10 наведено залежність коефіцієнта ежекції від геометричної характеристики ежектора при використанні як розпилювача відцентрово-струминної форсунки.

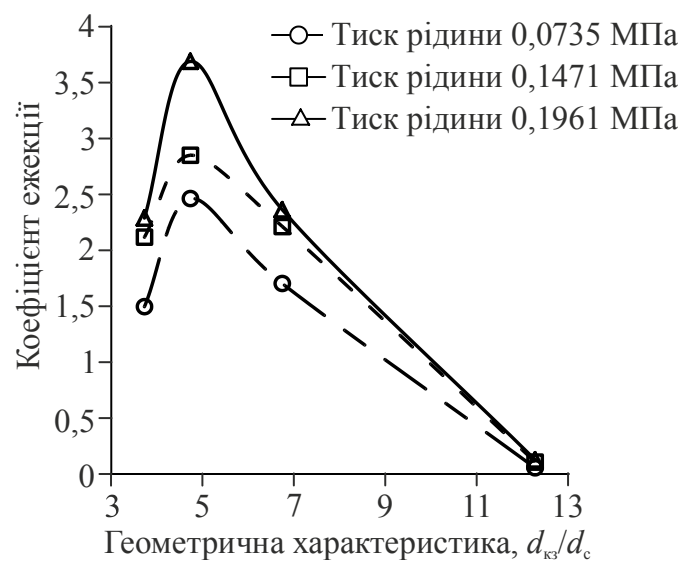

Рис. 10. Залежність об'ємного коефіціснта ежекції від відношення $d_{\text {к.3. }} / d_{\mathrm{c}}$ : тиск рідини $(0,735,1,47$ і 1,96$) \cdot 10^{5}$ Па

У ході дослідження ежекторів, у яких використано струминну та відцентрово-струминну форсунки, встановлено, що об'ємний коефіцієнт ежекції набуває максимального числового значення за головної геометричної характеристики $4,5 \ldots .5,5$.

\section{Висновки}

1. Проаналізовано роботу сульфітаторів, виявлено недоліки їх роботи та вказано основні напрями модернізації. Найпоширенішими $є$ сульфітатори струминного типу.

2. Створено лабораторну установку для дослідження гідродинаміки ежекційного апарата.

3. Встановлено закономірності гідродинаміки течії рідини в ежекційному апараті, в якому як розпилювач використано струминну і відцентрово-струминну форсунки.

4. Дослідами встановлено, що оптимальна геометрична характеристика ежектора для всіх типів розпилювачів становить 4,5...5,5. У типовому сульфітаторі з ежекційним апаратом, головна геометрична характеристика якого виходить за межі оптимуму і дорівнює 10,2 , не можна отримати максимальний коефіцієнт ежекції. Це пояснює причину нестабільної роботи сульфітатора та загазованості робочого місця.

5. Встановлено, що заміна розпилювача зі струминного на відцентровоструминний дає змогу якісно змінити картину гідродинаміки течії в ежекторі, гарантовано забезпечує збільшення коефіцієнта ежекції за меншої витрати рідини порівняно зі струминною форсункою. 


\section{Література}

1. Штангеев В.О. Современные технологии и оборудование свеклосахарного производства. В 2-х ч. Ч.2. - В.О. Штангеев, В.Т. Кобер, Л.Г. Белостоцкий и др.; Под ред. В.О. Штангеева. - Киев : «Цукор України». 2004. — 307 с.

2. Гребенюк С.M. Технологическое оборудование сахарных заводов / С.М. Гребенюк. Москва : Колос С, 2007. - 520 с.

3. Молотин Ю.И. Сульфитационная обработка соков, сиропов и екстрагента свеклосахарного производства. / Ю.И. Молотин, В.О. Городецкий // Журнал «Сахар». — 2013. № 9. - С. 38 .

4. Выскребиов В.Б. Утилизация сернистого ангидрида и расход серы / В.Б. Выскребцов // Журнал «Сахар». - 2003. — № 5. - С. 46- 48.

5. Вискребиов В.Б. Чому станція сульфітації іноді працює незадовільно / В.Б. Вискребцов, В.В. Пономаренко // Журнал «Цукор України». - 2011. - № 8(68). - С. 18-20.

6. Вискребиов В.Б. 3 досвіду експлуатації струминних сульфітаторів / В.Б.Вискребцов, Є.В.Щепкін // Науково-практичний галузевий журнал «Цукор України». - 2002. № 6(30). - C. 12-13.

7. Лямаев Б.Ф. Гидроструйные насосы и установки / Б.Ф. Лямаев. - Ленинград : Машиностроение. Ленинград. отдел., 1988. - 256 с. 